\title{
Pengaruh Pemberian Vitamin E Pada Tikus (Rattus norvegicus) Bunting yang Dipapar Asap Rokok Subakut terhadap Berat Badan Bayi Lahir Aterm
}

\author{
A'yunin Nelawati*, Soemardini ${ }^{* *}$, Bambang Prijadi***
}

\begin{abstract}
ABSTRAK
Vitamin $\mathrm{E}$ adalah antioksidan yang dapat melindungi tubuh dari radikal bebas. Asap rokok menghasilkan radikal bebas di dalam tubuh. Paparan asap rokok selama kehamilan dapat mengakibatkan hambatan pertumbuhan bayi dan berat badan lahir rendah (BBLR). Penelitian ini bertujuan untuk mengetahui pengaruh pemberian vitamin E pada tikus (Rattus norvegicus) bunting yang dipapar asap rokok subakut terhadap berat badan bayi lahir aterm. Penelitian ini menggunakan 20 tikus bunting yang dibagi menjadi 5 kelompok; kontrol negatif (P0), kontrol positif (P1), kelompok dengan 3 dosis vitamin E (P2:100, P3:200, P4:400 mg/kgbb/hari). Vitamin $\mathrm{E}$ diberikan sejak hari pertama hingga hari ke-19. Asap rokok dipaparkan pada hari ke-6 hingga hari ke-19. Tikus dibedah pada hari ke-20, bayi tikus ditimbang dan dihitung rata-rata berat badan lahirnya. Hasil penelitian menunjukkan adanya penurunan berat badan rata-rata $(p=0,044)$ pada P1 dibanding P0. Pada P2 terjadi peningkatan rata-rata berat badan lahir yang signifikan $(p=0,003)$, sedangkan peningkatan berat badan lahir pada P3 dan P4 tidak signifikan (masing-masing $p=0,085$ dan $p=0,467$ ). Kesimpulan penelitian ini adalah pemaparan asap rokok subakut dapat menurunkan berat badan lahir rata-rata, pemberian vitamin $\mathrm{E}$ dosis $100 \mathrm{mg} / \mathrm{kgBB} / \mathrm{hari}$ dapat meningkatkan berat badan lahir, dan pemberian vitamin $\mathrm{E}$ dosis 200 dan $400 \mathrm{mg} / \mathrm{kgBB} / \mathrm{hari}$ meningkatkan berat badan lahir bayi aterm .
\end{abstract}

Kata kunci: Asap rokok, Berat badan lahir aterm, Tikus (Rattus norvegicus), Vitamin E.

\section{Effect of Vitamin E Supplementation in Pregnant Rat (Rattus norvegicus) that Exposed with Subacute Cigarret Smoke to Aterm Birth Weight}

\begin{abstract}
Vitamin $\mathrm{E}$ is an antioxidant that can protect the body from free radicals. Cigarette smoke is free radicals source. Exposure to cigarette smoke during pregnancy can cause miscarriage, intrauterine growth restriction, and low birth weight. The aim of this study was to investigate the effect of vitamin $E$ in pregnant rat that exposed with subacute to cigarette smoke on aterm birth weight. Twenty pregnant rats were randomly divided into 5 groups, as follows: negative control group that was neither exposed to cigarette smoke nor treated by vitamin $E(P 0)$, positive control group that was exposed to cigarette smoke without vitamin $E$ supplementation (P1), three groups that were treated with 3 different doses of vitamin $E(P 2=100, P 3=200$, $\mathrm{P} 4=400 \mathrm{mg} / \mathrm{rat} / \mathrm{day})$. Vitamin $\mathrm{E}$ is given on day 1 to day 19 . Cigarette smoke was exposed to rats on day 6 to day 19. On day 20 of gestation, the rats were dissected, fetal rats were pondered and the average birth weight was calculated. The result showed that P1 decreased significantly compared to P1 $(p=0,044)$. In P2 group showed significantly increasing the average of birth weight $(p=0,003)$, while increasing the birth weight in P3 and P4 was not significant ( $p=0,085$ and $p=0,465$, respectively). In conclusion, subacute cigarette smoke exposure reduce the average of fetal birth weight and vitamin $E$ supplementation with dose of $100 \mathrm{mg} / \mathrm{rat} / \mathrm{day}$ can increase the average fetal birth weight, but vitamin $E$ supplementation with dose of 200 and $400 \mathrm{mg} / \mathrm{rat} / \mathrm{day}$ can not increase the average of aterm fetal birth weight.
\end{abstract}

Keywords: Aterm birth weight, Cigarette smoke, Rat (Rattus norvegicus), Vitamin E

* Program Studi S1 Kebidanan, FKUB

**Laboratorium Faal, FKUB

${ }^{* * *}$ Laboratorium Biokimia-Biomolekuler, FKUB 


\section{PENDAHULUAN}

Menurut WHO (2003), lebih dari 1 milyar orang di dunia menggunakan tembakau dan menyebabkan kematian lebih dari 5 juta orang setiap tahun. ${ }^{1}$ Menurut data Susenas (2001), jumlah perokok di Indonesia sebesar $31,8 \%$. Jumlah ini meningkat menjadi $32 \%$ pada tahun 2003, dan meningkat lagi menjadi $35 \%$ pada tahun $2004 .{ }^{2}$ Jumlah perokok aktif penduduk umur $>5$ tahun adalah 35,4 \% (65,3\% laki-laki dan 5,6\% wanita), berarti 2 diantara 3 laki-laki adalah perokok aktif. Lebih bahaya lagi 85,4 \% perokok aktif merokok dalam rumah bersama anggota keluarga. ${ }^{3}$ Satu pertiga sampai setengah dari wanita hamil terpapar asap rokok sebagai perokok pasif selama mereka di rumah, bekerja maupun di tempat umum. 4,5

Kehamilan adalah rangkaian peristiwa yang terjadi bila ovum dibuahi dan pembuahan ovum akhirnya berkembang sampai menjadi fetus yang aterm. ${ }^{6}$ Proses kehamilan sangat dipengaruhi oleh lingkungan. Agar kehamilan sehat maka ibu hamil harus berada di lingkungan dengan gaya hidup yang sehat pula. Larangan merokok di tempat umum yang belum tegas menyebabkan banyak ibu hamil terpapar asap rokok, padahal asap rokok mengandung sekitar 4000 bahan kimia toksik seperti nikotin, karbon monoksida (CO), asam sianida ( $\mathrm{HCN}), \mathrm{NH} 4$, acrolein, acetilen, benzaldehyde, urethane, benzene, methanol, coumarin, etikatehol-4, ortokresol, perilen dan radikal. ${ }^{7}$

Radikal bebas adalah molekul oksigen yang dalam interaksinya dengan molekul lain kehilangan sebuah elektron di lingkaran terluar orbitnya sehingga jumlah eletronnya ganjil . Radikal bebas sangat reaktif dan dapat menyebabkan kerusakan serta merugikan jaringan tubuh. Radikal hidroksil $(\mathrm{OH} \bullet)$ menyebabkan kerusakan oksidatif terhadap protein, DNA, lemak membran yang mengandung lebih dari satu ikatan rangkap pada rantai hidrokarbon (poly unsaturated) dan komponen sel lain. ${ }^{8}$

Peningkatan jumlah radikal bebas dalam tubuh akibat paparan asap rokok akan menyebabkan penurunan sistem pertahanan endogen terhadap radikal bebas. Kondisi ini disebut stres oksidatif. Stres oksidatif dapat menyebabkan kematian sel (apoptosis atau nekrosis) dan terlepasnya sel endotel dari dinding pembuluh darah. ${ }^{9}$ Tubuh juga terkena radikal bebas dari paparan lingkungan seperti asap rokok. ${ }^{10}$ Pembakaran rokok merupakan salah satu penghasil radikal bebas, oleh karena itu asap rokok mengandung zat-zat yang berbahaya bagi lingkungan termasuk ibu hamil sebagai perokok pasif. Paparan asap rokok bagi ibu hamil dapat berdampak buruk bagi kehamilannya karena meningkatkan resiko berat bayi lahir rendah (BBLR), penurunan fungsi paru-paru bayi, sudden infant death syndrome (SIDS), dan penurunan kadar asam folat di dalam serum maternal. ${ }^{11,12}$

Tubuh secara alami memiliki sistem proteksi terhadap radikal bebas yaitu superoksida dismutase (SOD), katalase, dan glutation peroksidase, namun pemaparan asap rokok menyebabkan meningkatnya jumlah radikal bebas dalam tubuh sehingga sistem pertahanan tidak mampu mengimbangi efek toksik radikal bebas. Salah satu upaya yang bisa dilakukan untuk mencegah kerusakan pada tubuh akibat radikal bebas ialah dengan pemberian antioksidan. Antioksidan melindungi sel dari kerusakan akibat radikal bebas. ${ }^{10}$ Vitamin $\mathrm{E}$ adalah senyawa yang larut dalam lemak dengan aktifitas antioksidan yang berbeda. ${ }^{13}$ Elektron tidak berpasangan dari radikal bebas sangat energik dan bereaksi cepat dengan oksigen untuk membentuk reactive oxygen species (ROS). Vitamin E merupakan antioksidan yang larut dalam 
lemak yang dapat menghambat produksi ROS ketika lemak mengalami oksidasi. ${ }^{10}$

Berat badan lahir rendah dapat disebabkan karena kekurangan nutrisi dan juga oksigenasi pada bayi sebagai akibat dari kerusakan pada jaringan plasenta yang disebabkan oleh serangan radikal bebas. Beberapa penelitian menunjukkan bahwa vitamin $E$ dapat melindungi dan mempertahankan fungsi sel dari serangan radikal bebas. ${ }^{14}$ Pemberian vitamin $\mathrm{E}$ dengan dosis 120 IU terbukti mampu menurunkan kadar MDA darah tikus yang diberi pakan tinggi lemak. ${ }^{15}$ Penggunaan dengan dosis $80 \mathrm{IU}$ juga telah dibuktikan mampu menurunkan secara nyata jumlah neuron yang mengalami nekrosa pada kondisi hiperglikemia. ${ }^{16}$ Sebagai antioksidan, vitamin $\mathrm{E}$ berfungsi sebagai donor hidrogen yang mampu mengubah radikal peroksil (hasil peroksidasi lipid) menjadi radikal tokoferol yang kurang reaktif, sehingga tidak mampu merusak rantai asam lemak dan sel menjadi terhindar dari kerusakan. ${ }^{17}$

Sejauh ini, belum diketahui apakah ada pengaruh pemberian vitamin $\mathrm{E}$ terhadap berat badan bayi tikus lahir aterm yang terpapar radikal bebas asap rokok subakut. Pada penelitian ini ingin diteliti tentang pengaruh pemberian vitamin $\mathrm{E}$ pada tikus (Rattus norvegicus) bunting yang dipapar asap rokok subakut terhadap berat badan bayi lahir aterm.

\section{BAHAN DAN METODE}

\section{Desain Penelitian}

Rancangan penelitian yang digunakan adalah randomized post test only control grup design dengan subjek dibagi menjadi 5 kelompok secara random. Tiap kelompok terdiri dari 4 tikus bunting. Kelompok kontrol negatif (P0) adalah tikus bunting tanpa paparan asap rokok dan tanpa pemberian vitamin E. Kelompok kontrol positif (P1) adalah tikus bunting yang dipapar asap rokok tanpa pemberian vitamin E. Kelompok
P2, P3, dan P4 adalah kelompok perlakuan yang dipapar asap rokok dan diberikan vitamin $\mathrm{E}$ dengan dosis berturut-turut 100 $\mathrm{mg} / \mathrm{kgBB} / \mathrm{hari}, 200 \mathrm{mg} / \mathrm{kgBB} / \mathrm{hari}$ dan 400 $\mathrm{mg} / \mathrm{kgBB} / \mathrm{hari}$ per oral dengan sonde. Pemberian vitamin $E$ pada hari ke-1 kebuntingan, sedangkan pemaparan asap rokok dilakukan secara subakut dimulai hari ke-6 kebuntingan. Perlakuan dihentikan pada hari ke-20 kebuntingan sekaligus pembedahan tikus untuk pengambilan bayi tikus. Kemudian diobservasi dan dibandingkan efek pemberian vitamin $E$ terhadap berat badan rata-rata pada kelompok kontrol dan kelompok perlakuan. Tikus yang dipilih adalah tikus (Rattus norvegicus) betina berusia minimal 8 minggu, telah siap kawin dan belum pernah melahirkan.

\section{Pembuntingan Tikus}

Pembuntingan dilakukan dengan mencampurkan hewan jantan dan betina dengan perbandingan 1:4 atau 1:1 pada pukul 16.00 WIB dan dipisahkan lagi besok paginya pukul 05.00 WIB. Jika keesokan harinya ditemukan vaginal plaque, maka hari tersebut dihitung sebagai hari pertama kebuntingan.

\section{Pengenceran Vitamin E}

Dosis vitamin $E$ untuk tikus dengan kondisi stres oksidatif adalah $200 \mathrm{mg} / \mathrm{kg} / \mathrm{hari}$, sehingga dosis perlakuan dibuat menjadi tiga yaitu $100 \mathrm{mg} / \mathrm{kgBB} / \mathrm{hari}, 200 \mathrm{mg} / \mathrm{kgBB} / \mathrm{hari}$ dan $400 \mathrm{mg} / \mathrm{kgBB} / \mathrm{hari}$. Penghitungan kebutuhan vitamin $E$ berdasarkan berat badan tikus adalah sebagai berikut :

Dosis 1:

Kebutuhan vitamin $\mathrm{E}=100 \mathrm{mg} / \mathrm{kg} / \mathrm{hari}$

Berat badan tikus $=0.25 \mathrm{~kg}$

Kebutuhan vit $\mathrm{E}$ tikus $=100 \times 0,25$

$$
\begin{aligned}
& =25 \mathrm{mg} / \mathrm{hari} \\
& =22.73 \mathrm{IU} \approx 23 \mathrm{IU}
\end{aligned}
$$

Ket : $1 \mathrm{IU}=1,1 \mathrm{mg}$ d-alpha-tokoferol 
Vitamin $\mathrm{E}$ untuk 4 ekor tikus selama 10 hari adalah $23 \mathrm{IU} \times 4 \times 10=920 \mathrm{IU}$, jumlah ini setara dengan 9,2 kapsul dan dibulatkan menjadi 10 kapsul natur E. Untuk mempermudah proses sonde, vitamin $\mathrm{E}$ diencerkan menggunakan minyak wijen sampai volume $1 \mathrm{ml}$. Oleh karena itu 10 kapsul vitamin $\mathrm{E}$ diencerkan dengan minyak wijen sampai volume akhir yang didapatkan adalah $40 \mathrm{ml}$. Dosis 2 (200 mg/kg/hari) dibuat dengan mengencerkan 20 kapsul natur $E$ dengan minyak wijen sampai volume $40 \mathrm{ml}$. Dosis 3 (400 mg/kg/hari) dibuat dengan mengencerkan 40 kapsul natur $\mathrm{E}$ dengan minyak wijen sampai volume $40 \mathrm{ml}$. Dalam penelitian ini, berat badan tikus dianggap sama yakni $0,25 \mathrm{~kg}$ sehingga satuan yang digunakan adalah $\mathrm{kg} /$ tikus/hari.

\section{Pemaparan Asap Rokok}

Pemaparan asap rokok menggunakan alat smoking pump (standar pemaparan asap rokok di laboratorium Farmakologi, FKUB). Tikus ditimbang berat badannya dengan neraca analitik sebelum dipapar asap rokok, tempat pemaparan dibersihkan dari kotoran dan sisa asap, nikotin yang melekat pada smoking pump dibersihkan terlebih dahulu, power dan self voltage diperiksa, rokok dipasang pada pipa sampai batas merah, tiga ekor dimasukkan ke dalam kotak dan segera ditutup, karena pada smoking pump hanya tersedia tiga ruangan, setiap pemaparan asap rokok dilakukan dengan menjalankan pompa selama 7,5 menit untuk 1 batang rokok, kemudian alat dimatikan, tutup dibuka dan selanjutnya tikus segera dipindahkan ke kandang semula, setiap pemaparan berikutnya kotak selalu dibersihkan dahulu dari sisa asap rokok perlakuan sebelumnya, pompa tetap dijalankan tanpa rokok untuk mengeluarkan sisa asap, tahap-tahap di atas diulangi untuk kelompok tikus berikutnya.

\section{HASIL}

\section{Berat Badan Lahir Rata-Rata}

Pada Tabel 1. ditampilkan berat badan bayi tikus dari lima kelompok perlakuan.

Tabel 1. Rata-rata berat badan bayi tikus

\begin{tabular}{|c|c|}
\hline Kelompok Perlakuan & Berat badan rata-rata $(\mathrm{g})$ \\
\hline Kontrol Negatif (P0) & 3.2 \\
\hline Kontrol Positif (P1) & 1,95 \\
\hline $\begin{array}{ll}\text { Kelompok } \quad(\mathrm{P} 2) \\
\end{array}$ & 4 \\
\hline $\begin{array}{ll}\text { Kelompok } \quad(\mathrm{P} 3) \\
\end{array}$ & 3 \\
\hline Kelompok & 2,37 \\
\hline
\end{tabular}

Berdasarkan Tabel 1. dapat diketahui bahwa pada kelompok perlakuan kontrol negatif (P0) rata-rata berat badan bayi tikus sebesar 3,2 gram. Pada tikus kelompok perlakuan kontrol positif (P1), rata-rata berat badan bayi tikus menurun hingga mencapai 1,95 gram dan merupakan kelompok dengan berat badan bayi tikus paling kecil. Pada kelompok P2 (vitamin E $100 \mathrm{mg} / \mathrm{kgBB} / \mathrm{hari}$ ), rata-rata berat badan bayi tikus meningkat hingga 4 gram dan merupakan kelompok dengan rata-rata berat badan terbesar. Pada kelompok P3 (vitamin E $200 \mathrm{mg} / \mathrm{kgBB} / \mathrm{hari}$ ), rata-rata berat badan bayi tikus sebesar 3 gram. Pada kelompok P4 (vitamin E 400 $\mathrm{mg} / \mathrm{kgBB} / \mathrm{hari})$, rata-rata berat badan tikus sebesar 2,37 gram. Berdasarkan hasil penelitian tersebut dapat disimpulkan bahwa pemberian dosis vitamin $E$ yang dapat meningkatkan secara optimal rata-rata berat badan bayi tikus lahir aterm yang dipapar asap rokok subakut adalah pada kelompok P2 yaitu sebesar $100 \mathrm{mg} / \mathrm{kgBB} / \mathrm{hari}$.

Pada Gambar 1. ditampilkan rata-rata berat badan bayi tikus pada masing-masing kelompok. 


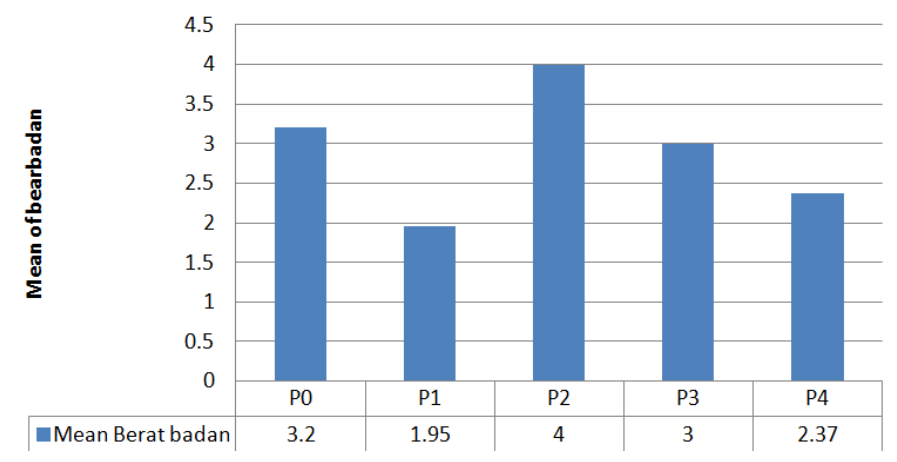

Gambar 1. Rata-rata berat badan bayi tikus pada masing-masing kelompok. Keterangan: (PO) kontrol negatif, (P1) kontrol positif, (P2) pemberian vitamin E $100 \mathrm{mg} / \mathrm{kgBB} / \mathrm{hari}$, (P3) pemberian vitamin E $200 \mathrm{mg} / \mathrm{kgBB} /$ hari, (P4) pemberian vitamin E $400 \mathrm{mg} / \mathrm{kgBB} / \mathrm{hari}$.

Berdasarkan gambar di atas dapat dilihat bahwa pemberian vitamin $\mathrm{E}$ akan mampu meningkatkan berat badan bayi tikus lahir aterm. Peningkatan tertinggi terdapat pada kelompok P2 (vitamin E $100 \mathrm{mg} / \mathrm{kgBB} / \mathrm{hari}$ ). Untuk mengetahui apakah rata-rata jumlah sel endotel pada tikus tersebut berbeda signifikan antar perlakuan maka dilakukan analisis oneway ANOVA $(a=0,05)$, diperoleh nilai $p=0,024(p<0,05)$ yang menunjukkan bahwa terdapat perbedaan bermakna rata-rata berat badan antar kelompok perlakuan. Untuk mengetahui perlakuan yang berbeda secara bermakna dilakukan analisa post hoc HSD Tukey $5 \%$.

Tabel 2. Hasil analisis uji post hoc Tukey

\begin{tabular}{c|c|c|c|c|c}
\hline Nilai p & P0 & P1 & P2 & P3 & P4 \\
\hline P0 & - & 0,044 & 0,181 & 0,730 & 0,168 \\
\hline P1 & 0,044 & - & 0,003 & 0,085 & 0,467 \\
\hline P2 & 0,181 & 0,003 & - & 0,100 & 0,012 \\
\hline P3 & 0,730 & 0,085 & 0,100 & - & 0,290 \\
\hline P4 & 0,168 & 0,467 & 0,012 & 0,290 & - \\
\hline
\end{tabular}

'eterangan: Nilai $p>0,05=$ tidak terdapat perbedaan bermakna antara dua kelompok Nilai $p<0,05=$ terdapat perbedaan bermakna antara dua kelompok

Berdasarkan hasil uji Tukey terhadap berat badan rata-rata bayi tikus dapat disimpulkan bahwa P1 mengalami penurunan berat badan rata-rata bayi tikus dengan nilai $p=$ $0,044(p<0,05)$ yang menunjukkan bahwa penurunan berat badan rata-rata bayi tikus tersebut bermakna dibanding dengan P0. P2 mengalami peningkatan berat badan ratarata bayi tikus nilai $p=0,003(p<0,05)$ yang menunjukkan bahwa peningkatan berat badan rata-rata bayi tikus tersebut bermakna dibanding P1. P3 dengan nilai $p=0,085$ dan $P 4 p=0,467 \quad(p>0,05)$ yang menunjukkan bahwa peningkatan berat badan rata-rata bayi tikus tidak bermakna dibanding dengan P1.

\section{Rata-Rata Jumlah Bayi}

Pada penelitian ini juga dilakukan analisis pengaruh pemberian Vitamin $\mathrm{E}$ terhadap jumlah bayi tikus yang dipapar asap rokok subakut. Rata-rata jumlah bayi seperti pada Tabel 3 berikut.

Tabel 3. Rata-rata jumlah bayi bayi tikus yang dipapar asap rokok subakut

\begin{tabular}{|c|c|}
\hline Kelompok Perlakuan & Jumlah rata-rata (g) \\
\hline Kontrol Negatif (P0) & 11 \\
\hline Kontrol Positif (P1) & 8 \\
\hline Kelompok & 9 \\
\hline Kelompok & 9 \\
\hline Kelompok & 7 \\
\hline
\end{tabular}

Berdasarkan data di atas, maka dilakukan uji kruskal-wallis untuk mengetahui apakah ada perbedaan yang signifikan rata-rata jumlah bayi pada kelompok perlakuan dan uji Mann- 
Whitney untuk mengetahui pengaruh antar perlakuan. Hasil analisis Kruskall Wallis, diperoleh nilai $p=0,229(p<0,05)$ yang menunjukkan bahwa tidak terdapat perbedaan bermakna pada rata-rata jumlah bayi antar kelompok perlakuan. Berdasarkan uji korelasi antara jumlah bayi tikus dengan berat badan rata-rata bayi lahir aterm didapatkan $p=0,645(p<0,05)$ yang berarti bahwa tidak ada korelasi antara jumlah bayi yang dilahirkan dengan berat badan rata-rata bayi tikus lahir aterm.

\section{PEMBAHASAN}

Hasil penelitian ini menunjukkan berat badan rata-rata bayi tikus dari kelompok kontrol negatif (P0) sebesar 3,2 gram, kelompok kontrol positif (P1) sebesar 1, 95 gram, P2 (vitamin E $100 \mathrm{mg} / \mathrm{kgBB} / \mathrm{hari}$ ) sebesar 4 gram, P3 (vitamin E 200 $\mathrm{mg} / \mathrm{kgbb} / \mathrm{hari}$ ) sebesar 3 gram, dan $\mathrm{P} 4$ (vitamin E $400 \mathrm{mg} / \mathrm{kgbb} /$ hari) sebesar 2,37 gram. Berat badan rata-rata bayi tikus aterm kelompok kontrol negatif pada penelitian ini adalah sebesar 3,2 gram yang berarti kurang dari berat badan bayi tikus aterm berdasar referensi yaitu 5-6 gram. ${ }^{18}$

Ada banyak faktor yang mempengaruhi berat lahir bayi tikus. Bobot lahir tikus dipengaruhi oleh pertumbuhan fetus sebelum lahir atau pertumbuhan selama kebuntingan. Variasi bobot lahir dipengaruhi oleh beberapa faktor, yaitu genotif (36\%), lingkungan fetal (30\%), lingkungan induk (18 $\%)$, kesamaan induk (7\%), nutrisi induk (6 $\%)$, dan umur induk (1\%)..$^{19}$

Pemberian vitamin E pada tikus yang terpapar asap rokok subakut diketahui berpengaruh terhadap jumlah bayi yang dilahirkan. Namun tidak ditemukan perbedaan yang signifikann pada jumlah bayi antara kelompok perlakuan berdasarkan hasil uji Kruskall Wallis ( $p=$ 0,$229 ; p<0,05$ ). Pada penelitian ini tidak ditemukan korelasi antara jumlah bayi dengan berat badan rata-rata bayi tikus lahir aterm $(p=0,645 ; p<0,05)$. Hasil ini tidak sejalan dengan penelitian terdahulu yang menyatakan bahwa semakin banyak jumlah anak menyebabkan semakin rendah berat badan lahir rata-ratanya. ${ }^{19}$ Pada Penelitian ini jumlah bayi tidak memiliki pengaruh terhadap berat badan lahir rata-rata disebabkan karena banyak faktor yang mempengaruhi variasi berat badan lahir. Pemberian vitamin E diketahui mempengaruhi berat badan lahir rata-rata sehingga tidak terlihat korelasi yang nyata antara jumlah bayi tikus dengan berat badan rata-rata bayi tikus lahir aterm.

Masa aterm pada kehamilan dapat bervariasi antara satu induk dengan induk lainnya dengan rentang waktu 20-24 hari. Tikus jarang menunjukkan kebuntingan semu. Seperti pada mencit, kita dapat diketahui kebuntingan tikus setelah ditemukan sumbat vagina atau dengan cara melakukan usapan vagina untuk melihat adanya spermatozoa. ${ }^{20}$ Pada penelitian ini hari pertama kebuntingan ditentukan dengan cara melihat sumbat vagina. Pada hari ke-20 bayi tikus dilahirkan dengan cara pembedahan. Hal tersebut kemungkinan menyebabkan berat badan lahir bayinya kurang dari 5 gram, karena bayi tidak dilahirkan secara spontan oleh induk. Meskipun hari ke-20 sudah masuk dalam rentang masa kebuntingan aterm, namun kelahiran aterm antara satu induk dengan induk lainnya bisa bervariasi.

Faktor nutrisi juga berpengaruh dalam perkembangan bayi. Kebutuhan pakan bagi seekor tikus setiap harinya kurang lebih sebanyak $10 \%$ dari bobot tubuhnya jika pakan tersebut berupa pakan kering dan dapat ditingkatkan sampai $15 \%$ dari bobot tubuhnya jika pakan yang dikonsumsi berupa pakan basah. ${ }^{20}$ Pada penelitian ini pakan yang diberikan berdasarkan standar pakan hewan coba laboratorium sebesar 50 garm/tikus/hari jadi pemberian pakan ini sebenarnya sudah sesuai dengan kebutuhan 
tikus pada masa reproduksi dan sudah lebih dari $10 \%$ berat badan tikus yaitu sekitar 200-250 gram. Akan tetapi pakan diberikan secara bersamaan untuk 4 tikus dalam satu kandang. Hal ini menyebabkan tidak terjaminnya secara pasti bahwa setiap tikus mendapatkan pakan sebesar 50 gram/tikus/hari. Kualitas pakan merupakan faktor penting yang mempengaruhi kemampuan tikus mencapai potensi genetik untuk tumbuh. Kebutuhan protein tikus adalah $12 \%$ (lengkap berisi 20 asam amino), lemak $5 \%$ dan serat kasar $\pm 5 \%$, makanan tikus juga harus mengandung vitamin $A$, vitamin $D$, asam linoleat, tiamin, riboflavin, pantotenat, vitamin B12, biotin, piridoksin dan kolin, serta mineral-mineral tertentu. ${ }^{20}$ Dalam penelitian ini pakan tikus yang digunakan memiliki kandungan air 12 $\%$, protein kasar $12-14 \%$, lemak kasar $4 \%$, serat kasar $6 \%$, abu 7,5\%, kalsium 1,2\% dan fosfor $0,8 \%$. Kurangnya beberapa komponen vitamin dalam pakan juga pemberian pakan secara bersamaan dalam satu kandang mungkin mempengaruhi pertumbuhan bayi pada masa kebuntingan sehingga memyebabkan berat badan lahir bayi juga kurang dari 5 gram. Selain itu faktor genotip (36\%), lingkungan fetal (30 $\%)$, dan kesamaan induk (7 \%) adalah faktor-faktor yang tidak bisa dikontrol pada penlitian ini. Sementara faktor lingkungan induk, seperti kandang dan suhu lingkungan adalah faktor yang telah dikontrol pada penelitian ini agar tidak mempengaruhi variasi berat badan lahir bayi tikus.

\section{Pengaruh Paparan Asap Rokok Subakut terhadap Berat Badan Rata-Rata Bayi Tikus}

Berdasarkan analisis statistik dengan uji post hoc HSD Tukey $5 \%$ terdapat perbedaan yang signifikan $p=0,044(p<$ 0,05 ) antara kelompok PO (kontrol negatif) dengan berat rata-rata sebesar 3,2 gram dibandingkan dengan P1 (kontrol positif) dengan berat rata-rata sebesar 1,95 gram. Penurunan berat badan disebabkan karena paparan asap rokok akan meningkatkan jumlah radikal bebas. Tubuh sebenarnya memiliki antioksidan endogen untuk melawan radikal bebas tapi apabila kadar radikal bebas terus meningkat maka antioksidan endogen tidak mampu mengimbangi peningkatan tersebut, sehingga terjadi stres oksidatif. Pada kondisi stres oksidatif akan terjadi peroksidasi lemak yang pada akhirnya akan merusak sel, selain itu hasil samping berupa MDA juga bersifat sitotoksik bagi sel endotel. Paparan asap rokok juga mengakibatkan sel endotel mengalami disjunction dengan jaringan dibawahnya sehingga akan terlepas ke dalam sirkulasi. ${ }^{21}$

Beberapa hasil penelitian menunjukkan ada percepatan degradasi NO akibat peningkatan ROS sehingga terjadi disfungsi endotel (ketidakseimbangan produksi vasokontriktor dan vasodilator) karena bioavailabilitas NO menurun. Radikal superoksida maupun Ox-LDL cholesterol bertanggungjawab atas peningkatan degradasi NO, bahkan radikal superoksida dapat secara langsung menginaktifkan NO melalui proses reaksi cepat membentuk peroksinitrit yang merupakan komponen yang sangat kuat dan memiliki daya hancur lebih kuat daripada superoksida. ${ }^{21}$ Kondisi disfungsi endotel yang terjadi secara terus menerus dapat menimbulkan apoptosis, yang kemudian menyebabkan denudasi endotel dan mempengaruhi jumlah sel endotel plasenta yang intak. ${ }^{22}$ Terjadinya kerusakan sel endotel pada plasenta dapat menyebabkan insufisiensi plasenta yaitu terjadi hambatan terhadap distribusi oksigen dan nutrisi sehingga bayi tidak mendapatkan oksignasi dan nutrisi yang adekuat. Penelitian sebelumnya menunjukkan adanya kerusakan plasenta yang ditunjukkan dengan penurunan jumlah sel endotel plasenta yang signifikan antara plasenta 
tikus kelompok kontrol dengan plasenta tikus yang dipapar asap rokok subakut. ${ }^{21}$

\section{Pengaruh Pemberian Vitamin E terhadap Berat Badan Rata-Rata Bayi Tikus yang dipapar Asap Rokok Subakut}

Penelitian ini menggunakan tiga dosis vitamin E berbeda yakni 100, 200, dan 400 $\mathrm{mg} / \mathrm{kgBB} /$ hari. Berdasarkan hasil penelitian sebelumnya, pemberian vitamin $E$ dengan dosis $100 \mathrm{mg} / \mathrm{kgbb} / \mathrm{hari}$ selama satu bulan terbukti mampu menurunkan jumlah leukosit dan neutrofil pada tikus yang dipapar asap rokok. ${ }^{23}$ Pemberian vitamin $\mathrm{E}$ dengan dosis 120 IU juga mampu menurunkan kadar MDA darah tikus yang diberi pakan tinggi lemak sehingga mampu mencegah terjadinya kerusakan sel. ${ }^{15}$

Seperti yang telah dijelaskan dalam pembahasan sebelumnya bahwa adanya kekurangan dalam penelitian ini menyebabkan berat badan lahir kurang dari 5 gram. Pada penelitian ini berat badan kelompok kontrol negatif (P0) sebesar 3, 2 gram. Namun secara statistik berdasarkan uji Tukey $5 \%$ pada P1 (kontrol positif) dan P2 (diberi vitamin E $100 \mathrm{mg} / \mathrm{kgBB} / \mathrm{hari}$ ) didapatkan peningkatan berat badan yang sangat signifikan dengan $p=0,003(p<$ $0,05)$. Vitamin $E$ dapat melindungi sel endotel plasenta dari kerusakan karena kemampuannya dalam memutus rantai reaksi radikal bebas dengan cara bereaksi dengan radikal peroksil, sehingga dapat mengurangi resiko terjadinya insufisiensi plasenta yang dapat menyebabkan penurunan berat badan bayi. 24,25 Hasil penelitian lain menyatakan dengan pemberian vitamin $\mathrm{E}$ dosis $100 \mathrm{mg} / \mathrm{kgbb} / \mathrm{hari}$ dapat mengurangi kerusakan sel testis akibat paparan asap rokok,akan tetapi dengan lama paparan 2 bulan. ${ }^{26}$

Mekanisme kerja Vtamin E dalam menghambat pembentukan radikal bebas dapat dijelaskan dengan reaksi radikal a-
Tocopherol (a-Toc ${ }^{*}$ dalam bulk lipids yang menghasilkan produk non radikal. ${ }^{27,28}$

$$
\mathrm{a}-\mathrm{Toc}^{*}+\mathrm{L}(\mathrm{R}) \mathrm{OO}-\rightarrow \text { non-radical products }
$$

Akan tetapi dalam penelitian ini pada pemberian vitamin $E$ dosis $200 \mathrm{mg} / \mathrm{kgBB} / \mathrm{hari}$ (P3) dan dosis $400 \mathrm{mg} / \mathrm{kgBB} /$ hari (P4) berat badan bayi tikus justru menurun. Hal ini mungkin disebabkan karena pemberian dosis yang terlalu tinggi yaitu 200 $\mathrm{mg} / \mathrm{kgbb} / \mathrm{hari}$ dan $400 \mathrm{mg} / \mathrm{kgBB} / \mathrm{hari}$. Walaupun secara umum vitamin $E$ berfungsi sebagai antioksidan namun dalam kondisi tertentu vitamin $\mathrm{E}$ juga dapat menjadi prooksidan. ${ }^{27}$ Vitamin E di dalam konsentrasi rendah cairan aqua ROO-, a-tocopherol (a$\mathrm{TocH}$ ) dapat menjadi pro-oxidan kuat untuk LDL. Radikal bebas a-tocopherol (a-Toc $\left.{ }^{*}\right)$ dapat terbentuk melalui mekanisme reaksi antara a-TocH dengan LOO- atau ROO-, sebagaimana reaksi berikut:

$$
\mathrm{a}-\mathrm{TocH}+\mathrm{L}(\mathrm{R}) \mathrm{OO}-\rightarrow \mathrm{a}-\mathrm{Toch}^{*}+\mathrm{L}(\mathrm{R}) \mathrm{OOH}
$$

dan juga reaksi radikal bebas a tocopherol $\left(\mathrm{a}-\mathrm{Toc}^{*}\right.$ ) dengan PUFA mengandung lemak $(\mathrm{L}-\mathrm{H}) .{ }^{27}$

$$
\mathrm{a}-\mathrm{Toch}^{*}+\mathrm{L}-\mathrm{H} \rightarrow \mathrm{a}-\mathrm{TocH}+\mathrm{L}^{-}
$$

Berdasarkan pembahasan di atas maka vitamin $E$ dapat memiliki efek sebagai antioksidan maupun peroksidan. Hasil ini sejalan dengan penelitian Richard B, et al., (2001) dan Vincent (1992) yang menyatakan bahwa a-tocopherol dapat menghambat pembentukan radikal bebas dengan bertindak sebagai pemulung LOO- maupun menginisiasi terbentuknya radikal bebas ROO-. 27,28

\section{KESIMPULAN}

Berdasarkan hasil penelitian mengenai pengaruh pemberian vitamin $\mathrm{E}$ pada tikus (Rattus norvegicus) bunting yang terpapar asap rokok subakut terhadap berat badan 
bayi lahir aterm, maka dapat disimpulkan bahwa:

1. Berat badan rata-rata bayi tikus pada kelompok kontrol negatif (PO) adalah sebesar 3,2 gram.

2. Pemaparan asap rokok subakut pada tikus selama masa kebuntingan (19 hari) dapat menyebabkan penurunan berat badan lahir tikus dengan nilai berat badan rata-rata bayi tikus pada kelompok kontrol positif (P1) adalah sebesar 1,95 gram.

3. Berat badan rata-rata bayi tikus yang terpapar asap rokok subakut dan diberi vitamin E 100mg/kgBB/hari (P2) adalah 4 gram dan, pada kelompok P3 (dosis $200 \mathrm{mg} / \mathrm{kgBB} / \mathrm{hari}$ ) adalah $3 \mathrm{gram}$, dan (dosis $400 \mathrm{mg} / \mathrm{kgBB} /$ hari) adalah 2,37 gram.

4. Pemberian vitamin $\mathrm{E}$ dengan dosis 100 $\mathrm{mg} / \mathrm{kgBB} /$ hari pada tikus bunting yang dipapar asap rokok subakut dapat meningkatkan berat badan lahir tikus secara signifikan. Sementara dosis 200 dan $400 \mathrm{mg} / \mathrm{kgBB} / \mathrm{hari}$ belum dapat meningkatkan berat badan lahir tikus secara signifikan.

\section{DAFTAR PUSTAKA}

1. (WHO) World Health Organization. The World Health Report 2003-Shaping the Future: Neglected Global Epidemics. Geneva: World Health Organization. 2003; p 83-102.

2. (WHO) World Health Organization. Prevention and Care of Illness, Neonates and Infats: 12 Key Family Practices. (Online). 2005. http://www.who.int/childadolescenthealth /Prevention/12 key.htm. Diakses 16 April 2013.

3. (DEPKES RI) Departemen Kesehatan Republik Indonesia. Rokok Membunuh Lima Juta Orang Setiap Tahun. (Online). 2011.http://www.depkes.go.id/index.php/ berita/press-release/458-rokok membunuh-lima-juta-orang-setiaptahun.html). Diakses 5 Maret 2012.

4. Rudatsikira EM, Knutsen SF, Job JS, Singh PN, Yel D, Montgomery SB et al. Exposure to Environmental Tobacco Smoke in the Nonsmoking Population of Cambodia. Am J Prev Med. 2008; 34(1):69-73.

5. Jordan TR, Price JH, Dake JA, Shah S. Adolescent Exposure to and Perceptions of Environmental Tobacco Smoke. J Sch Health. 2005; 75(5):17886.

6. Guyton AC and Hall JE. Textbook of Medical Physiology. 11th Edition. Philadelphia: Elsevier Saunders. 2010.

7. Aditama TY. Tuberkulosis, Rokok dan Perempuan. Jakarta: FKUI. 2006.

8. Marks DB, Marks AD, Smith CM. Biokimia Kedokteran Dasar. Cetakan I. Jakarta: EGC. 2000; Hal 321-330.

9. Aoshiba K, Tamaoki J, Nagai A. Acute Cigarette Smoke Exposure Induces Apoptosis of Alveolar Macrophages. Am J Physiol Lung Cell Mol Physiol. 2001; 281:L1392-1401.

10. Office Dietary of Supplement. (Online). 2011.http://ods.od.nih.gov/factsheets/vit amine/. Diakses 7 Maret 2012.

11. Goel P, A Radotra, I Singh, A Aggarwal, D Dua. Effects of Passive Smoking on Outcome in Pregnancy. Journal of Postgraduate Meicine. 2004; 50(1):1216.

12. Kristin $H H$, Emily RE, Robert MG, and M. Michele P. The Effect of Cigarette Smoke Exposure on Developing Folate Binding Protein-2 Null Mice. Reprod Toxicol. 2008; 26(3-4):203-209.

13. Shils ME, Shike M, Ross AC, Caballero B, Cousins R (Editors). Modern Nutrition in Health and Disease. 10 $10^{\text {th }}$ Edition. Baltimore: Lippincott Williams \& Wilkins. 2006;396-411.

14. Wahyuningsih. Pengaruh Vitamin $C$ dan E terhadap Jumlah Eritrosit dan Kadar 
Hemaglobin Darah Tikus Putih. Solo: Universitas Negeri Solo. 2009.

15. Yuliani. Pengaruh Pemberian Vitamin E terhadap Kadar Malonaldehid Plasma pada Tikus yang Diberi Pakan Lemak Tinggi. Jurnal Sains Veteriner. 2002; 20(1).

16. Wibowo BA. Kajian Histomorfologi Otak Tikus Putih pada Kondisi Hiprglikemia dan Pemberian Vitamin E. Skripsi. Bogor: Institut Pertanian Bogor. 2007.

17. Winarsih H. Antioksidan Alami dan Radikal Bebas. Cetakan 7. Jakarta: Kanisius. 2007; Hal 100.

18. Oktavianis. Efek Pemberian Asap Rokok terhadap Kehamilan Tikus Putih (Rattus norvegicus). Tesis. Padang: Universitas Andalas. 2011.

19. Hafez ESE. Reproduction and Breeding Techniques for Laboratory Animals. Philadelphia: Lea \& Febiger. 1970.

20. Smith $B j, \quad$ Mangkoewidjojo $S$. Pemeliharaan, Pembiakan dan Penggunaan Hewan Cobaan di Daerah Tropis. Jakarta: Universitas Indonesia Press. 1988.

21. Samsuria. Efek Asap Rokok pada Tikus (Rattus norvegicus) Bunting terhadap Tampilan Fisiologis Induk dan Anaknya Setelah Dilahirkan. Tesis. Bogor: Institut Pertanian Bogor. 2009; Hal 18-20.

22. Santoso D, Firani NK, Kusuma, AF. Pengaruh Pemberian Vitamin $E$ terhadap Peningkatan Jumlah Sel Endotel Plasenta Pars Maternalis Tikus (Rattus norvegicus) yang Terpapar Asap Rokok Subakut. Skripsi. Malang: Fakultas Kedokteran Universitas Brawijaya. 2013.
23. Squadrito $F$, Altavilla $D$, Squadrito $G$, Saitta A, Cucunotta D, Minutoli L, Deodato B, Ferlito M, Campo GM, Bova A, Caputi AP. Genistein Supplementation and Estrogen Relacement Therapy Improve Endothelial Dysfunction Induced by Ovariectomy in Rats. Cardiovascular Research. 2000; 45:454-462.

24. Yuniharilmy D. Efek Vitamin E terhadap Jumlah Total Leukosit dan Neutrofil Tikus Wistar yang Leukositosis Setelah Diberi Paparan Asap Rokok. Skripsi. Semarang: Universitas Diponegoro. 2011.

25. Murray KR, Granner KD, Rodwell WV. Biokimia Harper. Edisi ke-27. Jakarta: ECG. 2009.

26. Handayaningsih W. Pengaruh Antioksidan Vitamin E terhadap Jumlah Kerusakan Sel Testis Tikus Putih (Rattus norvegicus) yang Dipapar Asap Rokok. (Online). 2006. (http://studentresearch.umm.ac.id/index.php/dept_of_ biology/ article/ view /4183).

27. Richard BW, Barbara SV, Rachel AA, Jene ES, Michael JT. Pro-Oxidant Effect of Vitamin $E$ in Cigarette Smokers Consuming a High Polyunsaturated Fat Diet. Arterioscler Throb Vasc Biol. 2001; 21:1029-1033.

28. Vincent WB, Keith UI, and Roland S. Vitamin $E$ in Human Low-Density Lipoprotein when and How This Antioxidant Becomes A Pro-Oxidant. Biochem J. 1992; 288:341-34. 